\title{
Cultural Trends In Development Of Science And Technology In Indonesia And The Role Of Philosophy To Overcome It (Pancasila In Action)
}

\author{
Iriyanto Widisuseno* \\ Department of Linguistics, Faculty of Humanity, Diponegoro University Semarang, Central Java, \\ Indonesia
}

\begin{abstract}
Indonesian society is currently experiencing a cultural shift as an influence of the development of modern science and technology. The aim of this study reveals the phenomenon of cultural shifting of Indonesian society and to build a philosophical strategy to overcome the problem. Through qualitative descriptive explorations a posteriori method can identify and describe the symptoms of cultural change of society, to obtain a map of changes in socio-cultural values of the community. The philosophical synthetic heuristic method helps to show how the quality and relation of the object must be sought, giving way to the reconstruction of the basic frameworks of the existence of science. The results show that the development of science and technology today, on the one hand has facilitated the various needs of human life, but on the other hand has a negative impact on changes in thinking patterns, attitude and behavior of people who tend towards the development of practical, pragmatic and hedonistic. This problem arises because the development of science and technology increasingly separated from the basic framework of the existence of science, namely; ontology, epistemology and axiology. The development of science and technology needs to be directed back to the development model that puts Pancasila as the vision and orientation of strengthening the basic framework of the existence of science as a whole.
\end{abstract}

Keywords: cultural shift, framework of existence of science, Pancasila as paradigm,

\footnotetext{
${ }^{*}$ Corresponding author : widisusenoiriyanto@yahoo.co.id
} 


\section{Introduction}

Modern science and technology tend to create a practice and pragmatic system of life values [1]. The development of science and technology (IPTEK) is currently running fast, mastering various fields of human life, such as economic, social, cultural, education, information and communication. Technology in the field of information and communication has been able to create information and communication systems that are accurate, targeted and massive, able to penetrate the boundaries of each country's territory. Every nation can not escape from the intervention of the values of life of other nations. There is tension and tugging between the values of regional culture and global culture [2]. Modern technology leads to a shift in the culture of society, that is from the habit of way of thinking and behaving that based on the system the value of life once considered noble, while this part of society turns to the world of western life, which is value-oriented practical, pragmatic and empirical. As an implication, the hedonic, materialist and consumptive patterns of community life are becoming increasingly widespread in society. There is disorientation and distortion among the people, a cultural shift that leads the Indonesian nation to lose its identity [3]. As the nation faces fundamental problems in culture, philosophy plays an important role to resolve through its uniqueness, essence, and normative approach [4]. The discussion of the problem is described in detail into sub-issues as follows; (b) The phenomenon of cultural shifts in the development of science and technology in Indonesia, (c) Pattern of philosophical strategy in overcoming the problem of cultural shift in the development of science and technology.

\section{Method}

The discussion method using qualitative descriptions of a posteriori, and philosophical heuristics. The method of qualitative aposteriori descriptions, an essential explorative thinking through a combination of logical and empirical methods, to reveal the true meaning and significance of science and technology development and the phenomenon of cultural shifts in the development of science and technology in Indonesia. The method of philosophical heuristics, a new path of searching finds the basic framework of scientific existence as a philosophical strategy of problem solving.

\section{Results and Discussion}

\subsection{The meaning of cultural shift.}

Cultural shift can be interpreted as the movement of old life patterns of Indonesian people who have long been firmly upholding the core values of life that are considered noble and give the character of the nation to the pattern of modern life, ie ways of thinking attitude and behavior that is based on practical, pragmatic and positivistic value [6]. All the criteria of the truth of knowledge and the reality of life are measured on the basis of rational value, until its implementation on attitude and behavior [7]. 


\subsection{The phenomenon of cultural shifts.}

Phenomena in the development of science and technology today, namely specialization accompanied by technological discoveries in each field increasingly find autonomy, science is separate from the masters of science, very varied, sharpening the boundaries between the sciences and tends towards the disintegration ${ }^{[8]}$. Science develops towards its autonomy, with the reason to maintain the objectivity of truth, modern science is increasingly far from the rules of science that come from outside of science, such as moral and ethical rules ${ }^{[9]}$ Such phenomena illustrate the development of science and technology increasingly shifting from the elements of the framework of the actual existence of science; that is, away from the meanings and essential meanings of science, ignoring the right development methods for human interests, and not heeding the imperative rules that must be obeyed in the form of moral and ethical values as the direction of their development. It seems that in the development of science it is oriented only to the interests of the market and its technology, so that the technology resulting from the development of modern science does not touch the essential interests of human life. The pragmatic and economical development orientation of the technology only creates the social life of the Indonesian people which is dry in spirituality of moral and ethical values ${ }^{10]}$

Modern technology has extensively mastered many areas of life, and is intensively able to change the way people think (cultural patterns). Changes in the pattern of Indonesian society's culture began to shift to practical thinking patterns, pragmatic, empirical. This tendency leads to the development of dry patterns of ethical, moral, religious and historical values. It appears to be widespread consumer lifestyles, materialistic, hedonistic, demoralized and dehumanized. There are various crises in the country for example, the lower the public appreciation of: moral values, values of love for the homeland, the values of nationalism. The widespread cultural crisis can be witnessed in various forms such as disorientation and distortion of values in the lives of Indonesians. Disorientation is caused by people who are increasingly losing the basic values that have long been used as life orientation or life grip. The community experiences a shakiness in the view of life, easy to vacillate and easily affected by provocation that plunges. Distortion as a result of the fragility of the basic values of life, something that is considered noble now understood obsolete, while people prefer modern values that are not necessarily in accordance with the cultural values of the Indonesian nation. Life becomes bland, arid, and temperamental, easy to perform various acts of violence and anarchism. The challenge that the Indonesian people face today is the tendency for the development of science in the 21 st century to break away from the metaphysical theological environment toward autonomy in positivistic environments. Science enters quantum evolution that has the potential to uncover new zones and ecological niche for humans. If the process is misguided and its direction, this evolution can end with the extinction of the human species [11].

\subsection{A philosophical paradigm as a strategy to overcome the cultural shift}

Philosophical strategy, we imperatively put the vision and philosophical orientation to Pancasila as a paradigm of science and technology development. Pancasila as a paradigm contains several philosophical dimensions, namely the ontological, epistemological and axiological dimensions [12]. The ontological dimension means that the value of Pancasila values provides the basis for scientific assumptions and fosters interdisciplinary communication. The epistemological dimension, Pancasila value is used as method of thinking and benchmarks of truth. An axiological dimension means that Pancasila contains imperative values to give direction so that the scientific process can find the truth, and 
scientific behavior must be done with honesty. Axiologically the precepts of Pancasila as a systemic whole. Implementation of Pancasila as science development paradigm is as follows.

a. Ketuhanan Yang Maha Esa: (The God head of YME): Complement science creates a balance between rational and irrational, between reason and taste. This precepts puts man in nature as its part and not its center.

b. Kemanusiaan yang adil dan beradab (A just and civilized humanity): to give direction and to control science. Science is restored to its original function, that is for humanity and not just for certain groups or layers.

c. Persatuan Indonesia (The Unity of Indonesia), Implementing science as a means to unite in a pluralistic society pluralism by continuing to develop the values of Indonesian nationalism.

d. Kerakyatan yang dipimpin oleh hikmah kebijakksanaan dalam permusyawaratan /perwakilan (People's precepts, led by the wisdom in the deliberations/ representatives), offset the autodynamics of science and technology evolve itself freely. Experimentation of the application and dissemination of science of democracy should be deliberately represented, from policy, research to mass application.

e. Keadilan sosial bagi seluruh rakyat Indonesia : (Practice social justice for all Indonesians), Social justice also maintains a balance between the interests of individuals and society, because the interests of individuals should not be trampled by false interests. Individuality is the foundation that enables creativity and innovation.

\subsection{A philosophical action to overcome the cultural shift}

Philosophical actions in overcoming problems in the development of science and technology, first by building a ontological framework, namely formulating a philosophical vision and orientation based on the Pancasila paradigm as a foundation for the development of science. Then the epistemological step, namely developing the methodology of developing science and technology by putting the Pancasila paradigm as a knife of analysis in solving the problem. The next step is axiology, which describes the values contained in Pancasila as the basis and orientation of consideration for what science and technology are developed.

At the level of praxis, ontologically the results of the development of science and technology must be able to strengthen one's religiosity, enhance human dignity, foster a sense of nationalism, develop a democratic culture, and create justice for society. For this purpose epistemologically, ways of developing science and technology must be precise, representing a systemic perspective of the entire Pancasila precepts. Axiologically, it does not oppose religious principles, human values, nationalism, democracy and justice. The development of science must be returned to the meaning and intrinsic meaning (ontology), procedures or methods of proper development (epistemology), and basic imperative norms that must be obeyed such as ethics and morals as the direction of purpose for what the science was developed (axsiology). Therefore, every development of science or technology at least validity (reliability) and reliability (reliability) can be accounted for, both based on context of justification and context of discovery [13].

\section{Conclusion}

Changes in cultural patterns of society in the development of technology is a necessity, but the change should not be shifted from the basic values of life. has long been a grip of life. It takes a whole philosophical concept of human being so as not to be wrong in laying the basic assumptions of science, methods of development and direction of science and technology development goals. The development of science and technology in Indonesia should be 
directed to a development pattern oriented to strengthening the framework of the existence of science as a whole (ontology, epistemology and axiology). It needs the awareness of the wider community, of the importance of understanding that the development of science and technology must reflect a cultural process that can lead to the attainment of ultimate truth, that is to educate, prosper, and make dignity. For that required a scientific behavior that is full of honesty.

\section{References}

[1] Popper, Karl, R., Realism and The Aim Of Science, Roman Litlefied, Totowa, New Jersey (1983)

[2] Jarvie, J.C. Situational Logic and Its Reception, "Philosophy of the Social Sciences" Vol. 28. No. 3, p. 36, September (1998)

[3] Widisuseno, Iriyanto. 2012. Pidato Pengukuhan Guru Besar Filsafat, UNDIP Press. Semarang (1998)

[4] Widisuseno,,Iriyanto, Teori Pertumbuhan PengetahuanIlmiah Karl R. Popper dan Implementasinya, BP. UNDIP, Semarang (2016)

[5] Widisuseno, Iriyanto.. Buku Ajar Filsafat Ilmu, Pascasarjana, Semarang (2009)

[6] Widisuseno, Iriyanto. Culture Shift in Development of Science and Techology and Efforts to Creat A low Carbon Community in Indonesia (Study Implementation of Pancasila), Prosiding ICENIS, e3sconf, UNDIP (2018)

[7] Sinaga, Dinamika Perkembangan Pemikiran di dalam Agama-Agama, Kanisius, Jogjakarta (2000)

[8] Sutardjo.. Problematika Perkembangan Ilmu Pengetahuan dan Teknologi, Tarsito, Bandung (1992)

[9] Titus. H.. Living Issues in Philosophy, American Book Company, New York, USA (1994)

[10] Widisuseno, Iriyanto,. Study of Taoism Ethics and Its Implementation for Democratic Community Development in Indonesia, UNDIP Press, Semarang (2013)

[11] Jacob. T. Manusia, Ilmu dan Teknologi, PT. Tiara Wacana, Yogyakarta(1993)

[12] Wibisono, Koento. Validasi dan Validitas Pancasila sebagai Dasar dan Ideologi Negara. Makalah Seminar MPK, Undip, Semarang(1998)

[13] Van Peursen, C.A.. Susunan Ilmu Pengetahuan, P.T. Gramedia, Jakarta (1989) 